\title{
Status of an $\mathrm{MW}_{\text {th }}$ integrated gasification fuel cell power- generation system in China
}

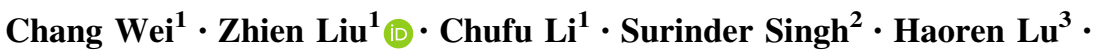 \\ Yudong Gong ${ }^{1}$ Pingping $\mathrm{Li}^{1} \cdot$ Hanlin $\mathrm{Wang}^{1} \cdot \mathrm{Xia} \mathrm{Yang}^{1} \cdot \mathrm{Ming}_{\mathrm{Xu}}{ }^{1}$. \\ Shujun $\mathrm{Mu}^{1}$
}

Received: 25 May 2020/Revised: 30 October 2020/Accepted: 3 April 2021/Published online: 16 May 2021

(C) The Author(s) 2021

\begin{abstract}
Here, we provide a status update of an integrated gasification fuel cell (IGFC) power-generation system being developed at the National Institute of Clean-and-Low-Carbon in China at the megawatt thermal $\left(\mathrm{MW}_{\mathrm{th}}\right)$ scale. This system is designed to use coal as fuel to produce syngas as a first step, similar to that employed for the integrated gasification combined cycle. Subsequently, the solid-oxide fuel-cell (SOFC) system is used to convert chemical energy to electricity directly through an electrochemical reaction without combustion. This system leads to higher efficiency as compared with that from a traditional coal-fired power plant. The unreacted fuel in the SOFC system is transported to an oxygencombustor to be converted to steam and carbon dioxide $\left(\mathrm{CO}_{2}\right)$. Through a heat-recovery system, the steam is condensed and removed, and $\mathrm{CO}_{2}$ is enriched and captured for sequestration or utilization. Comprehensive economic analyses for a typical IGFC system was performed and the results were compared with those for a supercritical pulverized coal-fired power plant. The SOFC stacks selected for IGFC development were tested and qualified under hydrogen and simulated coal syngas fuel. Experimental results using SOFC stacks and thermodynamic analyses indicated that the control of hydrogen/CO ratio of syngas and steam/CO ratio is important to avoid carbon deposition with the fuel pipe. A 20-kW SOFC unit is under development with design power output of $20 \mathrm{~kW}$ and DC efficiency of $50.41 \%$. A $100 \mathrm{~kW}$-level subsystem will consist of $6 \times 20-\mathrm{kW}$ power-generation units, and the $\mathrm{MW}_{\text {th }}$ IGFC system will consist of $5 \times 100 \mathrm{~kW}$ level subsystems.
\end{abstract}

Keywords Integrated gasification fuel cell (IGFC) - Solid oxide fuel cell - Stack module · Carbon dioxide capture · Oxygen-combustor

\section{Abbreviations}

ASR Area specific resistance $\left(\mathrm{ohm} \mathrm{cm}^{2}\right)$

BOP Balance of plant

CFD Computational fluid dynamics

$\mathrm{COE} \quad$ Cost of electricity (CNY/MWh)

DOE Department of Energy

Eff Efficiency (\%)

QGESS Quality guidelines for Energy system studies

IGCC Integrated gasification combined cycle

Zhien Liu

Zhien.liu@chnenergy.com.cn

1 National Institute of Clean-and-Low-Carbon Energy, Beijing, China

2 NICE America Research, Mountain View, USA

3 Nexant, San Francisco, USA
IGFC Integrated gasification fuel cell

$j \quad$ Current density $\left(\mathrm{A} / \mathrm{cm}^{2}\right)$

NETL National Energy Technology laboratory

OCV Open circuit voltage (V)

SLPM Standard liter per minute

SCPC Supercritical pulverized coal

SOFC Solid oxide fuel cell

$\mathrm{V} \quad$ Voltage $(\mathrm{V})$

\section{Introduction}

Coal-fired power plants provide most of the electricity needs in China. Coal is used because China has vast coal reserves and its low cost. Unfortunately, the carbon dioxide 
$\left(\mathrm{CO}_{2}\right)$ produced by such plants is a major source of $\mathrm{CO}_{2}$ emission and air pollution. In 2019, China's $\mathrm{CO}_{2}$ emission was more than the sum of that produced by Europe and the USA. In the Paris Agreement signed by international leaders in 2015, the Chinese government promised that $\mathrm{CO}_{2}$ emission in China would peak in 2035 and then decrease gradually to $<3$ gigatons (Gt) by 2050, compared with 9 Gt in 2015 (Jiang 2017). CHN Energy is one of the leading energy companies in China. It ranks 107 in the top500 companies worldwide. The coal mining of $\mathrm{CHN}$ Energy is up to 500 million metric tons per year. The total electricity generated by a coal-fired power plant is 190 gigawatts per year, about $45 \%$ of total electricity by CHN Energy. Old coal-fired power plants have lower efficiency (up to $35 \%-40 \%$ ) and also generate significant $\mathrm{CO}_{2}$ emission as well as other contaminants (e.g., nitric oxides, sulfur dioxide, and dust) to cause air pollution. A supercritical pulverized coal (SCPC) power plant has better efficiency $(\leq 48 \%)$ but its cost is higher if $\mathrm{CO}_{2}$ is captured and stored.

Integrated gasification combined cycle (IGCC) and integrated gasification fuel cell (IGFC) power-generation systems with $\mathrm{CO}_{2}$ capture have been developed recently to use coal effectively and to reduce air pollution and $\mathrm{CO}_{2}$ emission. Compared with IGCC, IGFC is more efficient and incurs an lower overall cost, especially for pressurized systems (Braun et al. 2012). IGFC is expected to be the most efficient power-generation system in coal-fired power-generation systems (Liese et al. 2010; Ghosh et al. 2006). A typical IGFC power-generation system comprises: (1) a coal-gasification subsystem to convert coal powder to syngas and remove all impurities; (2) hightemperature solid-oxide fuel-cell system (SOFC); (3) a subsystem for the capture, utilization, and storage of $\mathrm{CO}_{2}$. A simple IGFC system is similar to an IGCC system, but the gas turbine power island is replaced by a fuel cell power module. The fuel cell is a device to convert chemical energy to electricity through an electrochemical reaction. Hence, more efficient power generation can be achieved using IGFC than that using IGCC. The numerical simulation, by the National Institute of Advanced Industrial Science and Technology in Japan (Nomura et al. 2011), indicated that, power-generation efficiency of $64.5 \%$ (HHV) and 53.6\% (HHV) could be achieved using highgrade bituminous coal under ideal conditions and lowgrade coal, i.e., lignite and subbituminous coal, respectively. Developing an IGFC power-generation system to convert old coal-fired power plants to "green energy" to reduce $\mathrm{CO}_{2}$ emission and air pollution significantly is an urgent task for CHN Energy. Since July 2017, the National Institute of Clean-and-Low-Carbon Energy (NICE), which is fully owned by China Energy, has been developing an IGFC demonstration system working with key partners:
Huaneng Clean Energy Research Institute, China University of Mining Technology, and Huaqing Inc. High-quality coal syngas is being mass-produced at a coal-to-oil plant in Yinchuan (Ningxia Province, China) by a subsidiary of CHN Energy. This coal syngas will be used as fuel for the IGFC system being developed by NICE. Therefore, the purification processes for coal gasification and coal syngas will not be discussed here. Oxygen combustion of exhaust fuel from the fuel-cell system and $\mathrm{CO}_{2}$ capture will be discussed in a separate study (Wang 2021). The development status of the high-temperature SOFC power-generation system, including the system design and initial experimental results, are presented and discussed here.

\section{Economic analyses of the IGFC system}

First, comprehensive economic analyses for a typical IGFC system mentioned in the USA Department of Energy National Energy Technology Laboratory (DOE NETL) report (DOE/NETL 2014) were performed. This IGFC system consists of three main subsystems: (1) coal gasification and removal of various impurities; (2) SOFC powergeneration subsystem with anode loop recycling; (3) an oxygen combustion and heat recovery system generation for $\mathrm{CO}_{2}$ capture [Fig. 1; adapted from DOE/NETL reports (DOE/NETL 2014, 2015)]. An ASPEN Plus model was built to estimate the costs for Case 1.1 and Case 2.1 in the DOE NETL report using a cost of production (CoP) gasifier. The assumptions and parameters used in the model are listed in Table 1. Costing methods were used from various references. First, IGCC with a $\mathrm{CoP}$ gasifier without $\mathrm{CO}_{2}$ capture (Case B4A) was used for cost estimates for most non-SOFC components. Case B5A was employed to evaluate the costs of the Selexol plant and adapt them for IGFC costing cases. Case $12 \mathrm{~F}$ was used for estimating cryogenic separation of $\mathrm{CO}_{2}$ from other components (DOE/ NETL 2015). The Quality Guidelines for Energy System Studies (QGESS) capital cost scaling methodology was employed for scaling the components to the size estimated for the IGFC cases (DOE/NETL 2013). The USA estimates were converted to Chinese renminbi using a conversion rate of USD: RMB of 1:6.5. Figure 2 shows a comparison of several cases. We have reported the estimates for SCPC and SCPC with $\mathrm{CO}_{2}$ capture previously (Surinder 2018). The SCPC study was used to calculate the factors that could reduce the capital cost and operating cost between the USA and China. These factors were used to update the IGFC cases in the USA to calculate the IGFC costs in China. This is a simplified methodology for calculating IGFC costs in China. A more detailed analysis is suggested for an additional study in which each unit operation is modeled and sized specifically for Chinese conditions. 


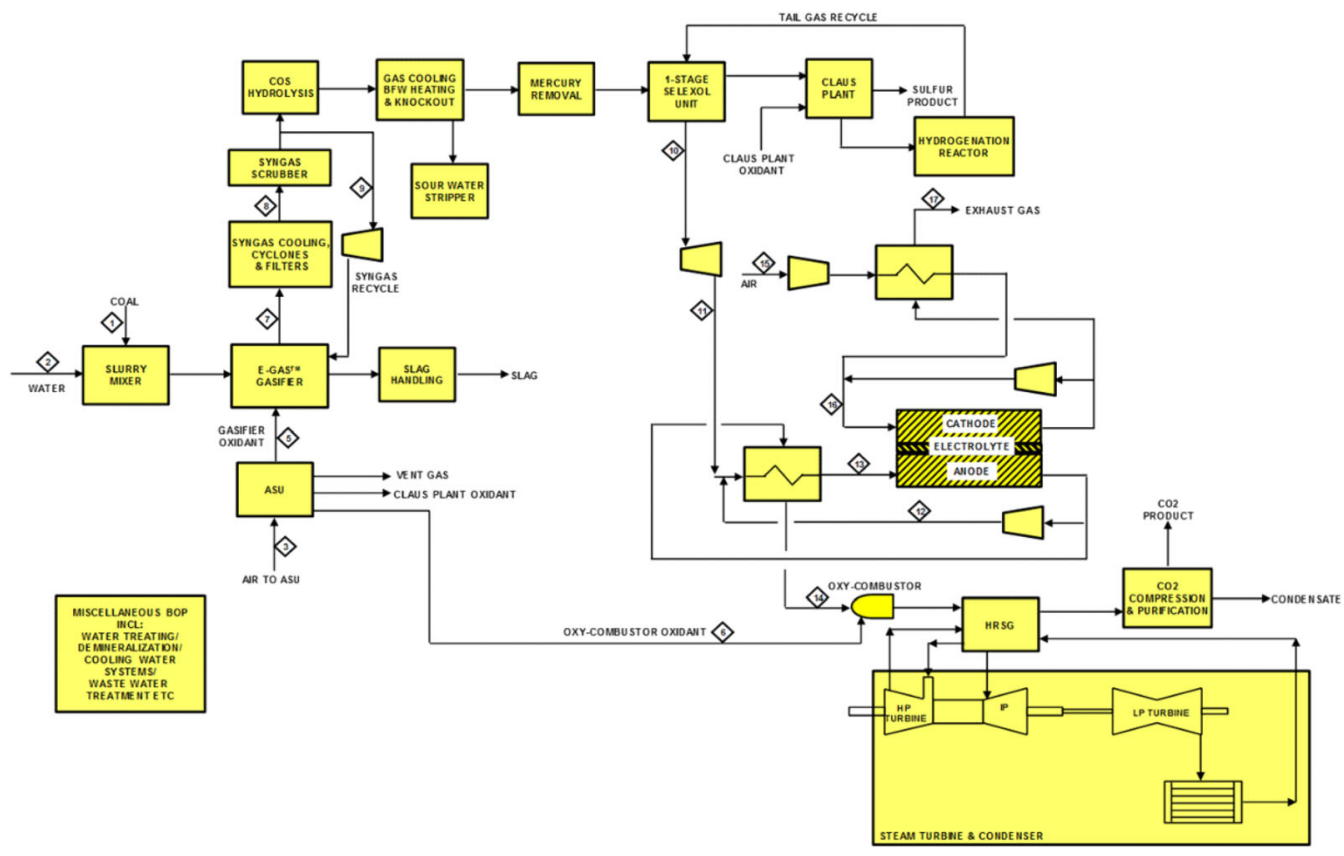

Fig. 1 A typical IGFC system for economic analysis (from DOE/NETL report, 2014)

Table 1 Assumptions used for the ASPEN plus model

\begin{tabular}{llll}
\hline Case & 1.1 & 1.2 & 3.1 \\
\hline Anode feed $\mathrm{CH}_{4}$ content (mol\%) & 5.8 & 5.8 & 10.9 \\
SOFC operating pressure (bar) & 1 & 2 & 8 \\
SOFC degradation rate (5\%/ & 1.5 & 0.2 & 0.2 \\
$\quad 1000$ h) & 140 & 141 & 70 \\
SOFC over potential (mV) & 80 & 80 & 85 \\
Capacity factor (\%) & 1463 & 1463 & 1463 \\
SOFC stack cost (RMB/kW) & 97 & 97 & 97 \\
Inverter efficiency $(\%)$ & & & \\
\hline
\end{tabular}

Such work is outside the scope of the present study. The Base IGFC case was modeled versus Case 1.1 in the DOE study with an SOFC degradation rate of 1.5\%/1000 h. The lower degradation rate case was modeled according to Case 1.2 of the DOE study with an SOFC degradation rate of $0.2 \% / 1000 \mathrm{~h}$. The advanced IGFC case was modeled according to Case 3.1 in the DOE study at a pressure of 8 bars instead of 20 bars used in the DOE study. A capacity factor of $80 \%$ was chosen for Case 1.1, 1.2, CN 1.1 and $\mathrm{CN}$ 1.2 and $85 \%$ for Case 3.1 and $\mathrm{CN} 3.1$ for comparison with DOE NETL cases. The results are shown in Fig. 2. Comparison of different cases revealed that China-based systems were consistently lower in cost compared with those in the USA. IGFC costs were higher compared to SCPC without and with $\mathrm{CO}_{2}$ capture at an SOFC degradation rate of $1.5 \% / 1000 \mathrm{~h}$. The IGFC system could become competitive compared with SCPC with $\mathrm{CO}_{2}$ capture if the SOFC degradation rate could be reduced to $0.2 \% / 1000 \mathrm{~h}$.
Such SOFC technology has been demonstrated at $250 \mathrm{~kW}$ in the USA and Japan (Kobayashi 2015). The IGFC system at higher pressure indicates a further reduction in cost of electricity (COE).

\section{Development of an IGFC system}

\subsection{Selection and evaluation of SOFC stacks}

CHN Energy is a traditional energy company. It has focused mainly on coal mining, coal-fired power plants, wind power, hydropower, and solar power in recent years: SOFC technology is not available in-house. We communicated with several domestic and international SOFC developers to obtain high-quality and low-cost stacks for this program. Based on quality, availability, cost, as well as mass-production capability and quality control, the stacks from Elcogen in Finland, Sanhuan in Chaozhou (China), Huaqing in Suzhou (China), and China University of Mining and Technology (Beijing) were considered for evaluation. Leakage was inspected for all incoming stacks, and followed by electrochemical testing using hydrogen fuel at $700-800{ }^{\circ} \mathrm{C}$ at ambient pressure based on stack specifications provided by the suppliers. More testing data from Sanhuan stacks were generated due to their availability. All testing stands/systems used for testing of SOFC stacks or modules in this work were designed and built by NICE with suppliers. Figure 3 summarizes the testing results (stack voltage and power output versus current 
density) of three individual stacks. For stack 1, the stack power output was $981 \mathrm{~W}$ at a current density of $250 \mathrm{~mA} /$ $\mathrm{cm}^{2}$, and increased to $1021 \mathrm{~W}$ at a current density of $270 \mathrm{~mA} / \mathrm{cm}^{2}$. If the current density was $>270 \mathrm{~mA} / \mathrm{cm}^{2}$, the stack voltage formed a tail, which was off the trend line. To better understand the effect of testing conditions on stack performance, the stack was tested under different fuel flow rates and all tests were done at $750{ }^{\circ} \mathrm{C}$ (stack 2 and 3 in Fig. 3). When the flow rate was increased from 9 standard liters per minute (SLPM) for stack 1- to 12 SLM for stack 2, and 13 SLPM for stack 3, the stack voltage showed good linearity.

The testing data of stack 1 were analyzed further to better understand the stack properties [e.g., area specific resistance $\left(\mathrm{ASR}, \mathrm{ohm}-\mathrm{cm}^{2}\right)$ ] and stack performance (e.g., fuel utilization and DC power efficiency) under different testing conditions. The electrochemical reaction on the anode side can be expressed as:

$\mathrm{H}_{2}+\mathrm{O}^{2-}=\mathrm{H}_{2} \mathrm{O}+2 \mathrm{e}^{-}$

Fuel utilization during stack operation is based on the fuel consumed by the electrochemical reaction divided by total inlet fuel to the stack, and can be written as Eq. (2) using hydrogen fuel as an example:

$U_{f}=n \times \frac{I}{2 F} \times \frac{1}{\frac{q_{v H_{2}}}{V_{m}}} \times 100 \%$

where, $I$ is the current through the fuel cell stack (ampere); $F$ is the Faraday's constant $(\mathrm{C} / \mathrm{mol})$; $\mathrm{n}$ is the number of cells connected in series in the stack; $q_{\mathrm{v} \mathrm{H} 2}$ is the hydrogen flow rate $(\mathrm{L} / \mathrm{s}) ; V_{\mathrm{m}}$ is the molar volume of a gas at standard conditions $(\mathrm{L} / \mathrm{mol})$. The DC power efficiency of the SOFC stack or module can be obtained by Eq. (3):

$\mathrm{DC}_{\mathrm{eff}}=\frac{P}{q_{\mathrm{mol}} \times Q} \times 100 \%$

where, $P$ is the stack power output $(\mathrm{W}) ; q_{\mathrm{mol}}$ is the fuel flow rate $(\mathrm{mol} / \mathrm{s}) ; Q$ is the low heat value of the inlet fuel $(\mathrm{J} / \mathrm{mol}$ ) whereby $Q=285,800 \mathrm{~J} / \mathrm{mol}$ for hydrogen.

Figure 4 summarizes the average stack ASR, fuel utilization, and DC power efficiency $v s$. current density at an average temperature of $750{ }^{\circ} \mathrm{C}$ with fixed fuel (9 SLPM) and air flow (25 SLPM) rates. At a current density of $250 \mathrm{~mA} / \mathrm{cm}^{2}$, the stack average ASR, fuel utilization, and DC power efficiency were $0.305 \Omega \mathrm{cm}^{2}, 82.7 \%$, and $61.3 \%$, respectively. Upon increasing the current density from 250 to $270 \mathrm{~mA} / \mathrm{cm}^{2}$, the stack average ASR, fuel utilization, and DC efficiency increased to $0.420 \Omega \mathrm{cm}^{2}$, $90.7 \%$, and $63.4 \%$, respectively, and a tail started to form from the voltage $v s$. current density curve (Fig. 3). Most likely fuel starvation occurred in a local area within the stack (especially near the stack outlet) when the current density was $\geq 270 \mathrm{~mA} / \mathrm{cm}^{2}$ with a fuel flow rate of 9
SLPM. In general (as expected), the ASR curve showed three distinct regions. At a low current density, the cell potential dropped as a result of activation polarization. Steam has a significant effect on anode polarization (e.g., hydrogen absorption and dissociation on Ni particles) and the charge can be transferred easier under an electric field. Hence, stack ASR decreased significantly with increasing current density (hydrogen fuel is pure hydrogen and the steam content in the fuel increased with increasing current density). At moderate current densities, the cell potential decreases linearly with current due to ohmic losses. Therefore, stack ASR showed almost no change with current density at $0.10-0.25 \mathrm{~A} / \mathrm{cm}^{2}$. At high current densities $\left(>0.25 \mathrm{~A} / \mathrm{cm}^{2}\right)$, the decrease in cell potential departs from a linear relationship with current density as a result of more pronounced concentration polarization. Operating the Sanhuan stack at a current density of $\sim 250 \mathrm{~mA}$ or fuel utilization of $\sim 80 \%$ appeared to be safe.

Short-term stack durability was tested $\leq 540 \mathrm{~h}$ under different conditions (Fig. 5). In period one, the fuel flow and air flow was 13 SLPM and 36 SLPM, respectively, and then the fuel flow was reduced to 10.6 SLPM while keeping air flow constant in period 2. Within both periods, stack degradation was observed. In period 3, air flow was increased to 69 SLPM while the fuel flow was unchanged. In period 4, the stack current was decreased from 24 to 22 A, and back to 24 A for period 5. Stack degradation trend was not noticeable for periods $3-5$ even though the duration is not long enough.

\subsection{Operating conditions for the designed system}

The IGFC system being developed will be operated under coal syngas rather than hydrogen fuel. Therefore, the stack performance under coal syngas must be evaluated and the operating conditions for the designed system must be defined. The composition of coal syngas available for operation of the IGFC system is approximately $61.8 \% \mathrm{H}_{2}$, $36.7 \% \mathrm{CO}$, and $1.1 \% \mathrm{~N}_{2}$ with a minor content of $\mathrm{CO}_{2}$ and $\mathrm{CH}_{4}$. Based on thermodynamics, carbon monoxide (CO) tends to form carbon under certain conditions: "reverse Boudouard reaction" (Eq. (4)). This is an exothermal reaction and is thermodynamically favored at $<500{ }^{\circ} \mathrm{C}$ based on thermodynamic analyses (Fig. 6). The carbon formed can be deposited on the inner surface of the fuel pipe to block the fuel flow channel or enter the stack with fuel gas stream and be deposited on the anode surface. The stack performance would be affected under either case. The contact material and properties of the material surface can also affect carbon formation. The amount of carbon formation at different temperatures was analyzed using ASPEN Plus for the syngas with different $\mathrm{H}_{2} / \mathrm{CO}$ ratio in the syngas (Fig. 6a-c). When $\mathrm{H}_{2} / \mathrm{CO}$ ratio is 1.68 


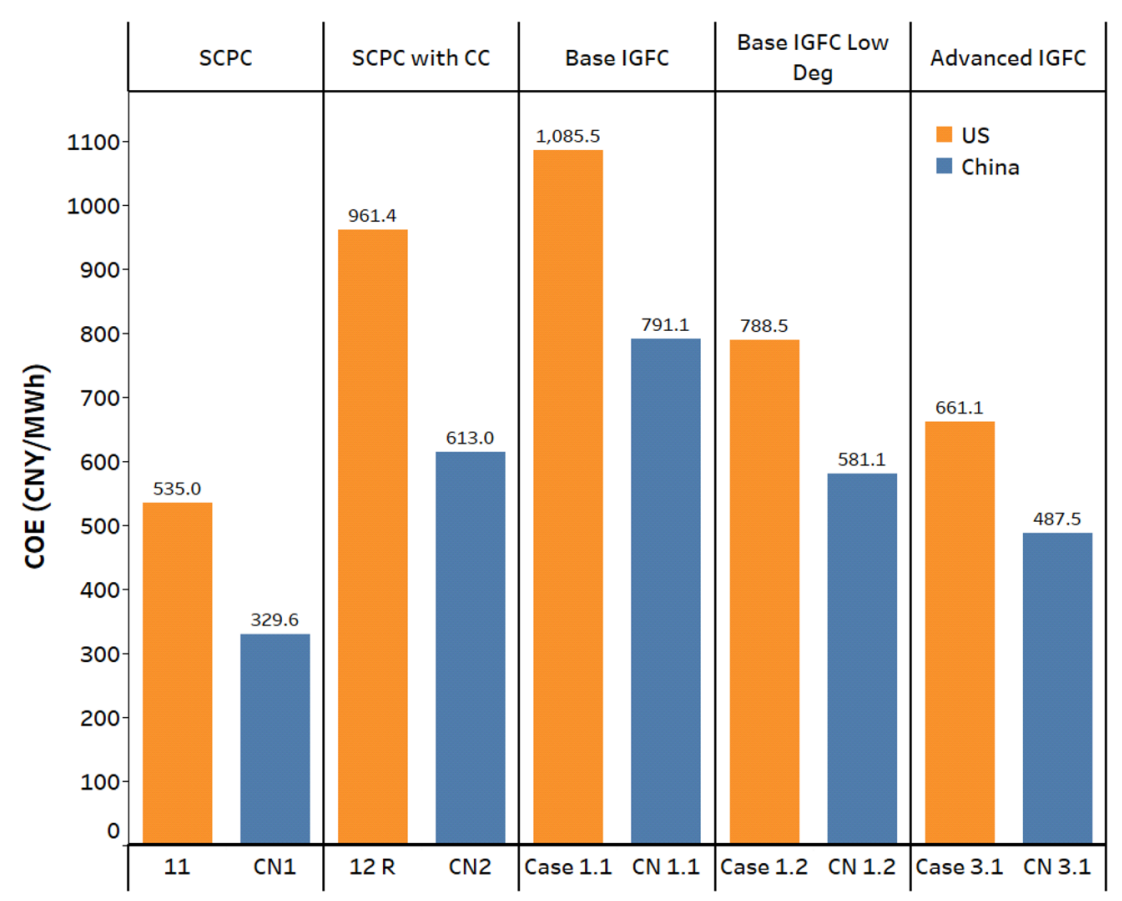

Fig. 2 Cost of electricity (COE) of various cases of IGFC systems as compared with SCPC without and with $\mathrm{CO}_{2}$ capture for the USA and China

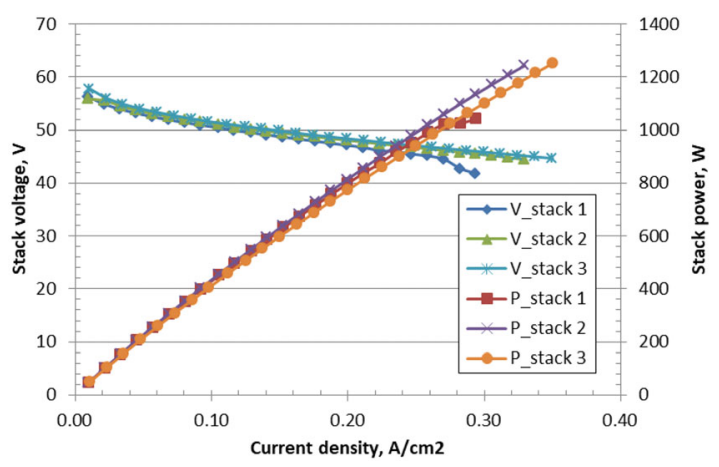

Fig. 3 V-I curves of SOFC stack (fuel flow rate (in SLPM) is 9.0 for stack $1,12.0$ for stack 2 , and 13 for stack 3 )

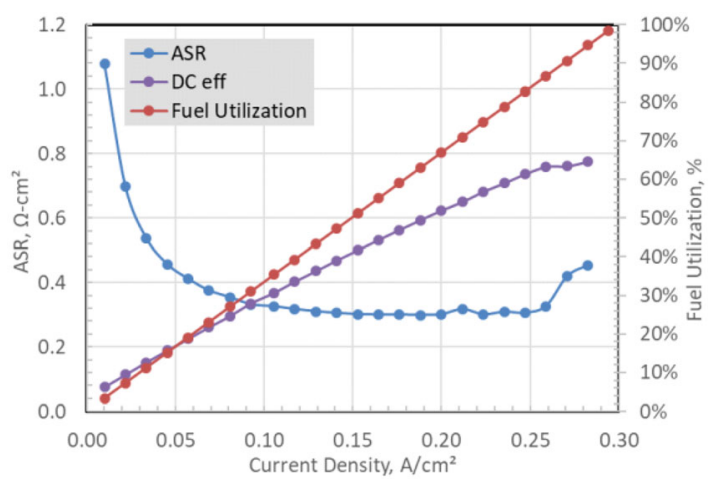

Fig. 4 SOFC stack average ASR, DC power efficiency, and fuel utilization versus current density

$(61.8 \% \mathrm{H}, 37.7 \% \mathrm{CO})$, the high end temperature for carbon formation was decreased from about $400{ }^{\circ} \mathrm{C}$ to $300{ }^{\circ} \mathrm{C}$ with increasing steam/CO ratio from 1 to 1.15 . When the $\mathrm{H}_{2} / \mathrm{CO}$ ratio was $2.3\left(69.7 \% \mathrm{H}_{2}, 30.3 \% \mathrm{CO}\right)$, the high-end temperature for carbon formation changed to $200{ }^{\circ} \mathrm{C}$ and the steam/CO ratio, when changing from 0.8 to 1.0 , showed no significant effect on the carbon-formation temperature (which is determined by the thermodynamics of the reaction). Above this temperature, the change in the Gibbs free energy of reactions (4), G, is positive and the reaction would not occur. If the $\mathrm{H}_{2} / \mathrm{CO}$ ratio was increased further to $2.9\left(74.4 \% \mathrm{H}_{2}, 25.6 \% \mathrm{CO}\right)$, the highest temperature for carbon formation would decrease to $150{ }^{\circ} \mathrm{C}$ even without steam addition. From a kinetics view point, the reaction speed would be too slow at lower temperatures and reaction (4) may not occur because the fuel gas stream will pass this temperature range at high speed ( $\sim 14$ SLPM) under the operating conditions of the system.

$\mathrm{CO}(\mathrm{g}) \rightarrow \mathrm{C}(\mathrm{s})+\mathrm{CO}_{2}(\mathrm{~g})$

Stack testing was also done to better understand its performance and behavior under coal syngas (Fig. 7). To ensure that this specific stack had the same performance as that of the other stacks under hydrogen, the stack was tested first under hydrogen at a flow rate of 13 SLPM at $750{ }^{\circ} \mathrm{C}$. The $\mathrm{V} / \mathrm{j}$ curve $\left(\mathrm{V}_{-} 1^{\text {st }} \mathrm{H}_{2}\right)$ showed good linearity, and the stack generated $1252 \mathrm{~W}\left(\mathrm{P}_{-} 1^{\text {st }} \mathrm{H}_{2}\right)$ at a current density of $330 \mathrm{~mA} / \mathrm{cm}^{2}$, which indicated a good stack. Then, the fuel was switched to simulated coal syngas with 
a composition of $61.8 \% \mathrm{H}_{2}$ and $37.7 \% \mathrm{CO}$ (steam/CO ratio was 1). The open circuit voltage (OCV) change was as expected due to the $\mathrm{pO}_{2}$ change in the fuel stream, and the $\mathrm{V} / \mathrm{j}$ curve was linear up to a current density of $270 \mathrm{~mA} /$ $\mathrm{cm}^{2}$.

Above that current density, both the voltage curve and power curve tailed down from the trend line of the original plot. The test was shut-down for inspection. Significant deposition of carbon within the fuel inlet pipe was identified. The stack was reheated to $750{ }^{\circ} \mathrm{C}$ under a safe gas (5\% $\mathrm{H}_{2}$ balanced with nitrogen), purged with hydrogen at $750{ }^{\circ} \mathrm{C}$, and then tested again after the OCV had stabilized. The $\mathrm{V} / \mathrm{j}$ curve of the second test under hydrogen $\left(\mathrm{V} \_2^{\text {nd }}\right.$ $\mathrm{H}_{2}$ ), in general, overlapped with $\mathrm{V}_{-} 1^{\text {st }} \mathrm{H}_{2}$. Hence, the carbon damage to stack performance was temporary and recoverable if the fuel stream was switched from simulated syngas to hydrogen. Analyses of the test set-up after testing indicated that the steam was added to the fuel stream near the entrance of the furnace, where the temperature may have been much higher than the temperature range of carbon formation. Hence, carbon was possibly formed before the steam was added to the fuel inlet pipe.

A second stack test was undertaken at $725{ }^{\circ} \mathrm{C}$ (stack average temperature) using simulated coal syngas (61.8\% $\mathrm{H}_{2}, 37.7 \% \mathrm{CO}$, steam/CO ratio: $\left.\sim 0.7\right)$ as fuel to ensure that the steam was added to the fuel stream at a lower temperature before carbon could be formed. The stack performance was stable during testing. A series of tests were completed at current densities between 258.2 and $282.9 \mathrm{~mA} / \mathrm{cm}^{2}$ with high voltage per cell (Table 2). A stack power of $1022 \mathrm{~W}$ and DC efficiency of $53.2 \%$ were achieved. Fuel utilization was $\leq 84.6 \%$ with no sign of fuel starvation. However, carbon was observed within the fuel inlet system during after-test inspection. This phenomenon may have been due to the lower steam/CO ratio or insufficient mixing between the fuel gas and steam.

After successful single-stack testing, a four-stack module was tested using pipeline coal syngas at the coal-to-oil plant in Yinchuan. During testing, the coal syngas was mixed with partial hydrogen to obtain a composition with a

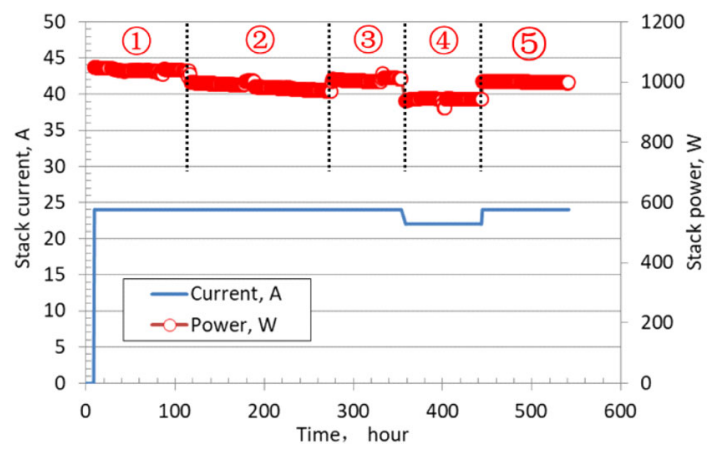

Fig. 5 SOFC stack short term durability at $750{ }^{\circ} \mathrm{C}$
$\mathrm{H} 2 / \mathrm{CO}$ ratio 1.68:1

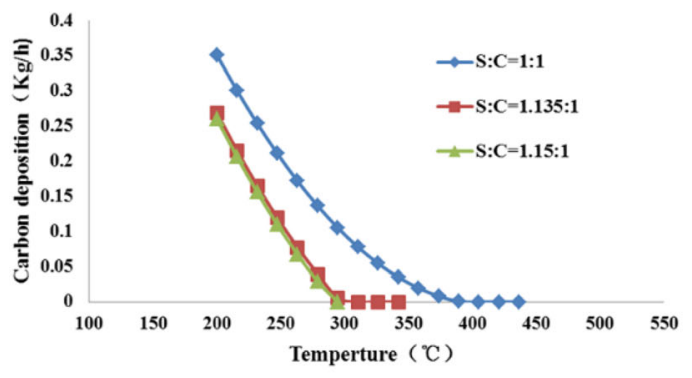

(a) $\mathrm{H} 2 / \mathrm{CO}=1.68(61.8 \% \mathrm{H} 2,37.7 \% \mathrm{CO})$

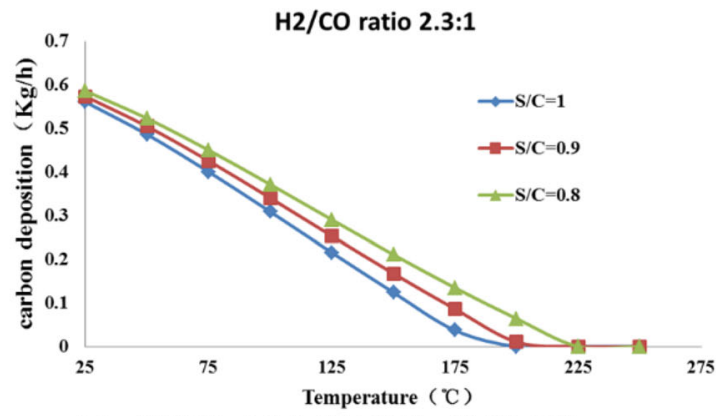

(b) $\mathrm{H} 2 / \mathrm{CO}=2.3: 1\left(69.7 \% \mathrm{H}_{2}, 30.3 \% \mathrm{CO}\right)$

H2/CO ratio 2.9:1

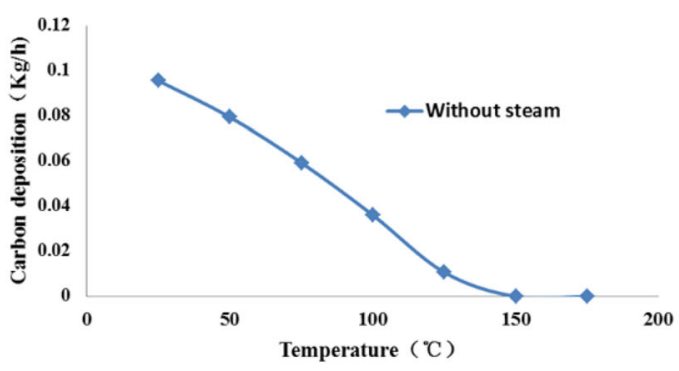

(c) $\mathrm{H} 2 / \mathrm{CO}=2.9: 1(74.4 \% \mathrm{H}, 25.6 \% \mathrm{CO})$

Fig. 6 Potential carbon deposition within fuel pipes for coal syngas with different $\mathrm{H} / \mathrm{CO}$ ratios using ASPEN Plus

higher $\mathrm{H}_{2} / \mathrm{CO}$ ratio of $2.8\left(72.9 \% \mathrm{H}_{2}, 26.0 \% \mathrm{CO}\right.$, steam/CO ratio $=1)$. The module power generation, fuel utilization, and DC power efficiency were $1.4 \mathrm{~kW} /$ stack, $84.5 \%$, and $53 \%$, respectively. The module was operated under a mixture of coal syngas and hydrogen for $\leq 350 \mathrm{~h}$ without noticeable degradation. Post-test analyses showed no carbon deposition in the fuel pipeline. Detailed experimental results will be published separately (Xu 2021).

Based on thermodynamic analyses and performanceverification tests of the stack, a coal syngas composition with a $\mathrm{H}_{2} / \mathrm{CO}$ ratio from 1.68 to 2.8 could be used as fuel for an IGFC power-generation system. If the syngas had a lower $\mathrm{H}_{2} / \mathrm{CO}$ ratio, more steam would be required to mix with the coal syngas at $>100{ }^{\circ} \mathrm{C}$ and below the temperatures where carbon formation was thermodynamically favored within the surface of the fuel inlet pipeline to 
Table 2 Test results for the SOFC stack with syngas

\begin{tabular}{llllll}
\hline $\begin{array}{l}\text { Test } \\
\text { No. }\end{array}$ & $\begin{array}{l}\text { Current } \\
\text { density }(\mathrm{mA} / \\
\left.\mathrm{cm}^{2}\right)\end{array}$ & Voltage $(\mathrm{V})$ & $\begin{array}{l}\text { Stack } \\
\text { power } \\
(\mathrm{W})\end{array}$ & $\begin{array}{l}U_{\mathrm{f}} \\
(\%)\end{array}$ & $\begin{array}{l}\text { DC } \\
\text { efficiency } \\
(\%)\end{array}$ \\
\hline 1 & 258.2 & 0.845 & 943.9 & 80.7 & 51.2 \\
2 & 282.9 & 0.835 & 1022.4 & 82.8 & 51.9 \\
3 & 280.6 & 0.837 & 1016.3 & 84.6 \\
\hline
\end{tabular}

Notes: (1) Operating conditions were controlled by adjusting the current density and fuel flow rate, (2) Stack average temperature: $725{ }^{\circ} \mathrm{C},(3)$ Steam/CO ratio: $\sim 0.7$

prevent carbon deposition, which could affect the system performance if the steam content was too high. If the coal syngas had a higher $\mathrm{H}_{2} / \mathrm{CO}$ ratio, carbon deposition could be prevented with less steam (or even no steam) in the fuel stream. More data on stack performance with a different composition of coal syngas and operating conditions are needed to achieve the highest power generation using the available coal syngas, or obtaining a coal-syngas composition which may benefit the power generation and efficiency of the IGFC system.

\subsection{Development of a $20-\mathrm{kW}$ SOFC power- generation unit}

A simplified IGFC system flowchart is shown as Fig. 8 in which pipeline coal syngas is used. Sulfur is removed before the syngas enters into SOFC stacks. After an electrochemical reaction in the stack, outlet fuel (which contains about $10 \%-20 \%$ of flammable material) is fed into an oxygen-combustor to convert $\mathrm{H}_{2}$ into steam and $\mathrm{CO}$ into $\mathrm{CO}_{2}$. After passing through a heat-recovery system, steam is condensed and removed, and $\mathrm{CO}_{2}$ is enriched to $>95 \%$ for capture. Based on this flowchart, a 20-kW SOFC power-generation unit has been in development since April 2019 using the performance data of single-stack and fourstack modules obtained under hydrogen and simulated

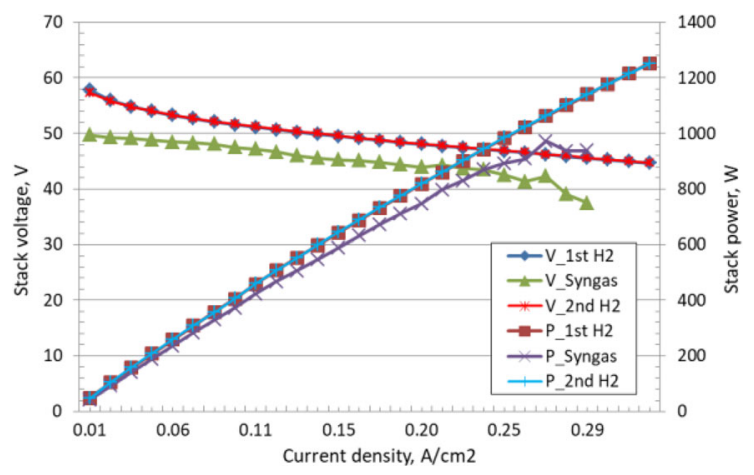

Fig. 7 SOFC stack performance under $\mathrm{H}_{2}$ (flow rate: 13 SLPM) and simulated coal syngas $\left(61.8 \% \mathrm{H}_{2}, 37.7 \% \mathrm{CO}\right.$, flow rate: 13 SLPM with a steam/CO ratio of 1.1 ) syngas or real coal syngas as fuel. The system process flow diagram is shown as Fig. 9. To clarify, this process flow diagram represents operation of the $20-\mathrm{kW}$ power-generation unit under steady state. During system start-up or shutdown, a start-up gas burner will heat the system to the designed operating conditions or to provide extra heat during system shut-down to control the cooling rate. The fuel system comprises a mixing tank to thoroughly mix coal syngas and steam at $>100{ }^{\circ} \mathrm{C}$ to prevent carbon formation in the fuel inlet before entering the stack, and a heat exchanger to heat the fuel stream to the desired temperature (which is $\sim 700{ }^{\circ} \mathrm{C}$ for the stack selected for our IGFC system). The fuel flow is single pass without recycling and the designed fuel utilization is $80 \%$. The exhaust fuel, after cooling and separating the water from the gas stream, will be fed into an oxygen-combustor to burn the residual fuel and enrich $\mathrm{CO}_{2}>95 \%$ for capture, which can

Table 3 Designed operating conditions of a $20-\mathrm{kW}$ power-generation system

\begin{tabular}{lll}
\hline Parameter & Design condition & Max. power output \\
\hline Power output $(\mathrm{kW})$ & 14.9 & 20.0 \\
Coal syngas flow rate $(\mathrm{kg} / \mathrm{h})$ & 4.89 & 6.57 \\
Air flow rate $(\mathrm{kg} / \mathrm{h})$ & 188.13 & 290.00 \\
Current density $\left(\mathrm{A} / \mathrm{cm}^{2}\right)$ & 0.250 & 0.336 \\
Stack tower voltage $(\mathrm{V})$ & 175.6 & 171.2 \\
DC efficiency $(\%)$ & 51.70 & 50.41 \\
Fuel utilization $(\%)$ & 80 & 80 \\
Heat loss $(\mathrm{kW})$ & 2 & 2 \\
\hline
\end{tabular}

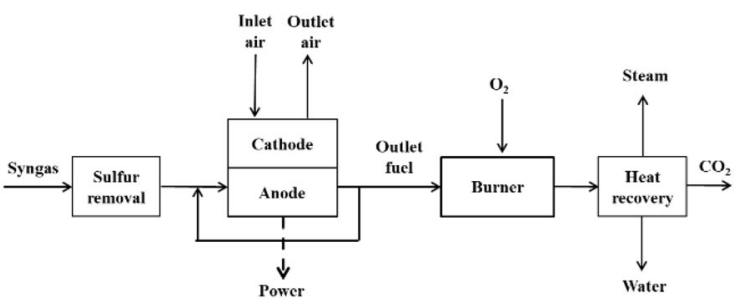

Fig. 8 Flowchart for an IGFC system using pipeline coal syngas 


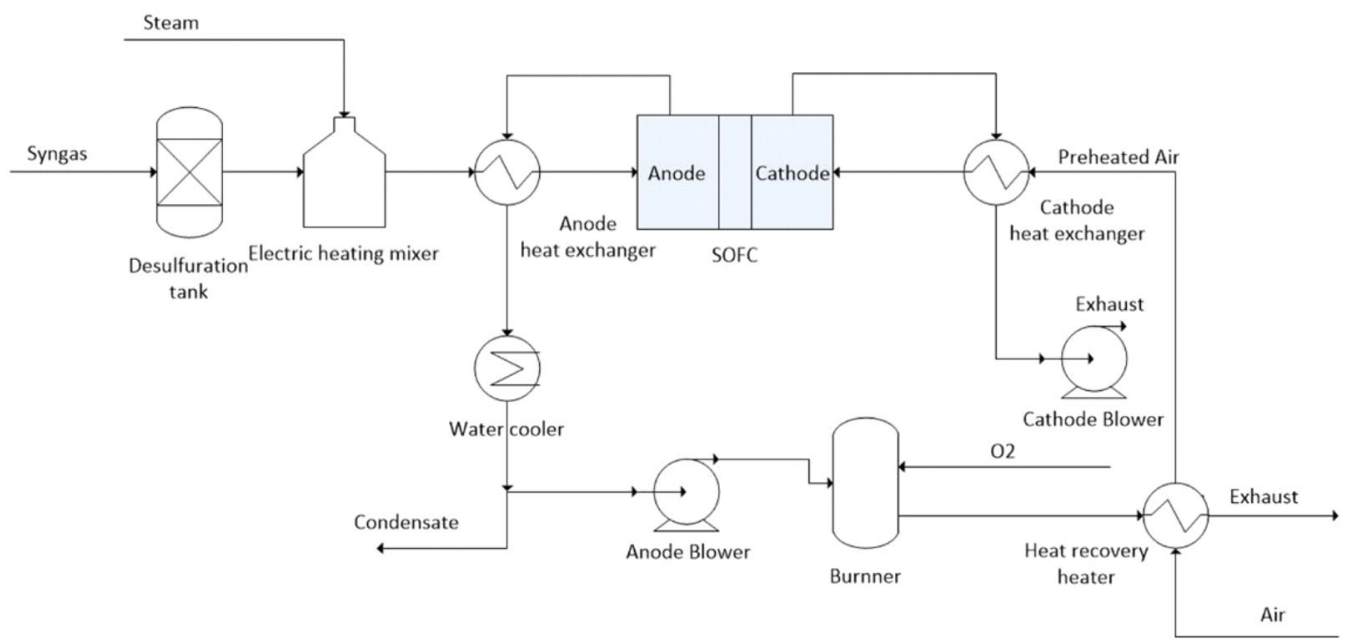

Fig. 9 Process flowchart of a 20-kW SOFC system

be stored or utilized, such as producing $\mathrm{H}_{2}-\mathrm{CO}$ syngas through co-electrolysis of $\mathrm{CO}_{2}$ and steam. The detailed experimental results will be published separately (Wang 2021). The stack module contains four stack towers. Each tower was built from four stacks, which can generate a maximum power of $\sim 20 \mathrm{~kW}$ under a current density of $336 \mathrm{~mA} / \mathrm{cm}^{2}$ and $171.2 \mathrm{~V} / \mathrm{stack}$ tower, respectively.

During a long-term steady-state operation, the module was designed to operate at $0.25 \mathrm{~A} / \mathrm{cm}^{2}$ and the power output was $15 \mathrm{~kW}$ (Table 3). Computational fluid dynamics (CFD) simulation was conducted to better understand the fuel flow and air flow within the stack module because they are important for heat management and keeping a healthy stack during operation. The simulation results were promising (Fig. 10). The air flow was quite uniform and the variation in fuel flow was within $\pm 5 \%$, which is acceptable for the system operation under design conditions. Uniform fuel flow will ensure no fuel starvation in any local area within the stack during system operation. Such uniform air flow could ensure that the temperature difference of all stacks in the module can be controlled within specifications. That is, the air inlet temperature of each stack will be $700{ }^{\circ} \mathrm{C}$ and outlet temperature will be $\leq 800{ }^{\circ} \mathrm{C}$ to maintain optimal performance and a healthy stack. The cathode loop consists of a gas start-up burner, and the hot exhaust gas can be used to heat up cold air if the system starts at room temperature. During steady operation of the system, the inlet air is heated through a heat exchanger. Figure 11 is the assembly sketch of the 20-kW SOFC power-generation system without the oxygen-combustor. On the back of the sketch, a hotbox shows where the SOFC module is installed. The hotbox is designed to keep the fuel cell module at constant temperature during steady-state operation via selection of insulation material to minimize heat loss and control the gas flow

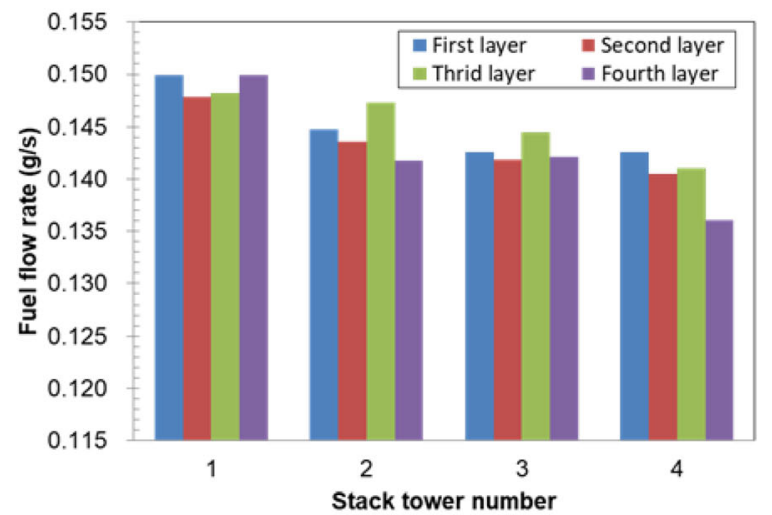

(a) Fuel flow distribution in SOFC stacks within $20 \mathrm{~kW}$ module

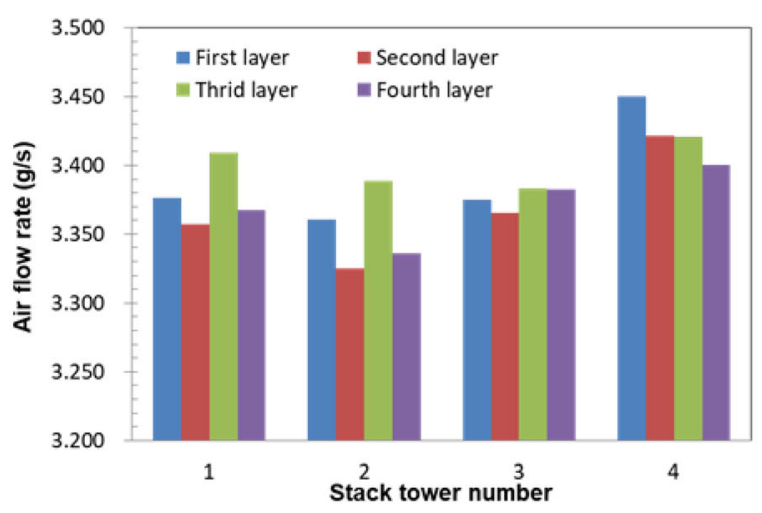

(b) Air flow distribution in SOFC stacks of $20 \mathrm{~kW}$ Imodule

Fig. 10 Gas-flow distribution in SOFC stacks of a $20-\mathrm{kW}$ module

rate through the cathode loop. The front part is the balance of plant (BOP), including fuel, air, and safe gas (to protect the SOFC module during emergency shutdown), pipe line, control valves, flow meters, pressure meters, inlet fuel, air preheaters, exhaust fuel, and air blowers. The corner box is the control system. There is no external reformer and most 


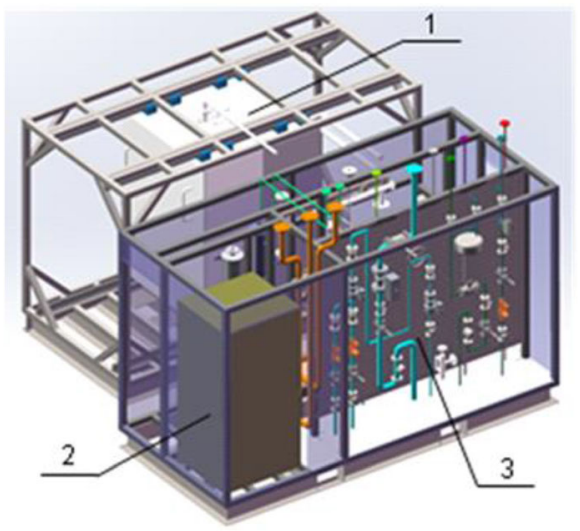

Fig. 11 A 20-kW SOFC power-generation system under development and construction (1: hotbox with stack module, 2: control and data acquisition, 3: BOP)

$\mathrm{CO}$ in the fuel gas stream will be converted to $\mathrm{CO}_{2}$ within the fuel cell stack. This reaction is exothermal, and the released heat may help self-sustainable operation of the system. However, the temperature difference between the cathode inlet and outlet will be monitored closely to ensure the outlet temperature is $\leq 800{ }^{\circ} \mathrm{C}$.

\subsection{Conceptual design of a megawatt thermal (MWth) IGFC system}

The conceptual design of a 500-kW IGFC power-generation system is shown in Fig. 12. The system consists of $5 \times 100 \mathrm{~kW}$-level subsystems which can be controlled separately, and the generated DC power is converted to AC power. There are 5-6 SOFC modules within each subsystem, which are connected electrically in parallel. If a module malfunctions or needs maintenance, other modules will not be affected and can continue to generate power. There are multiple stack towers within each module. These stack towers are connected electrically in parallel. In each stack tower, an individual stack is connected electrically in series.

The beauty of this design is that any damage, repair, or maintenance of individual stack tower, module, or subsystem will not affect operation of the other stack towers, modules, or subsystem. Based on Table 3, the design voltage of the stack tower during steady-state operation is $172.2 \mathrm{~V}$. This voltage may be too low for direct DC/AC conversion; boosting to a higher DC voltage before conversion to $\mathrm{AC}$ power may be required. The desired DC voltage is dependent on the technology of the advanced DC/AC converter. The small amount of power loss through each $\mathrm{DC}$ booster and $\mathrm{AC}$ converter during system design will be considered.

The layout sketch of a $100 \mathrm{~kW}$-level SOFC powergeneration system is shown as Fig. 13. It consists of $6 \times 20-\mathrm{kW}$ fuel cell modules. Each module can generate $15-\mathrm{kW}$ DC power during steady-state operation. All SOFC modules (including the hotbox) are located on one side of the layout, and the control system is located on another side. Gas pipe lines, heat exchangers, fuel preheaters, air preheaters, and blowers lie between them. The footprint of this $100 \mathrm{~kW}$-level SOFC system is approximately $7 \mathrm{~m} \times 30 \mathrm{~m}$.

Based on the conceptual design and selected SOFC stacks, materials and key components of the BOP, the initial cost model of the $100 \mathrm{~kW}$-level fuel cell system was established (Fig. 14). The stack cost was $30.4 \%$ which, in general, is the stack cost percentage in a SOFC power-

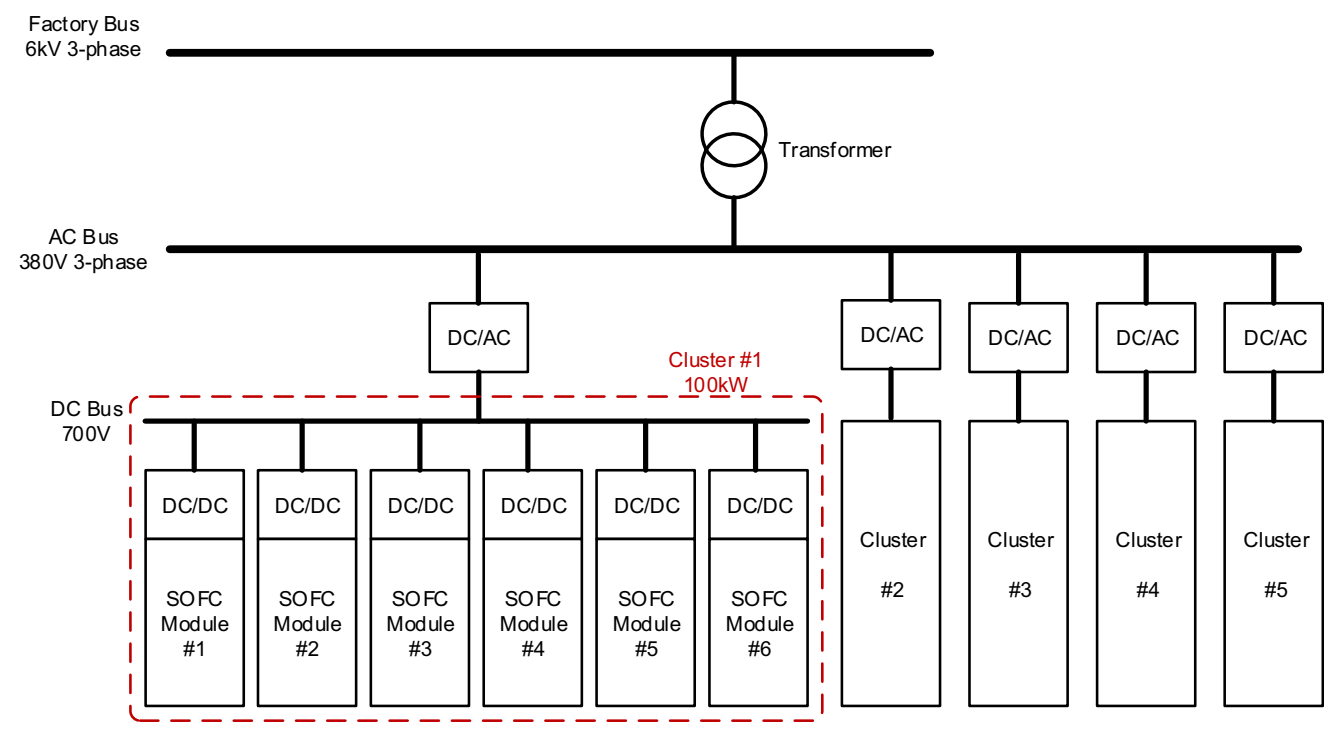

Fig. 12 Conceptual design of a 500-kW SOFC power-generation system. It comprises a $5 \times 100 \mathrm{~kW}$-level subsystem 


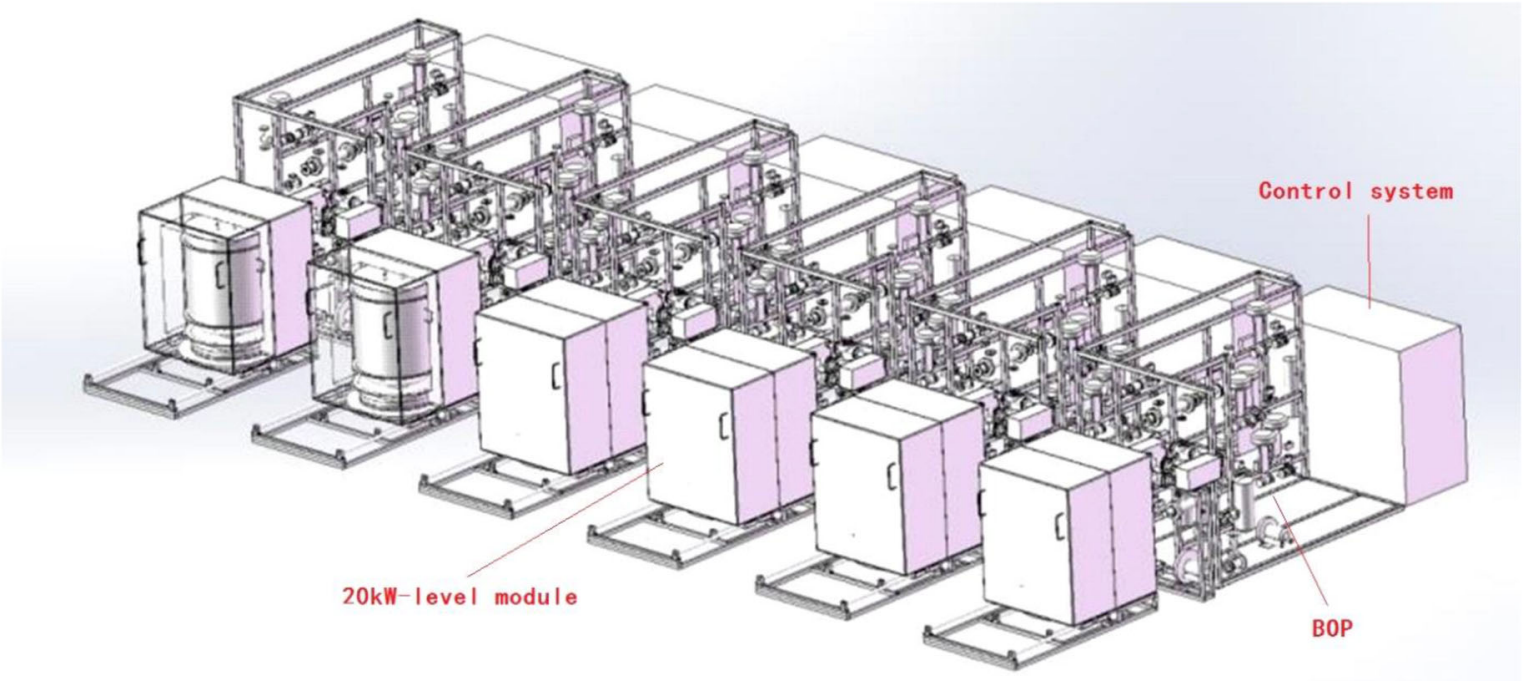

Fig. 13 Conceptual design of a $100 \mathrm{~kW}$-level SOFC power-generation system. It consists of $6 \times 20-\mathrm{kW}$ modules for steady-state operation

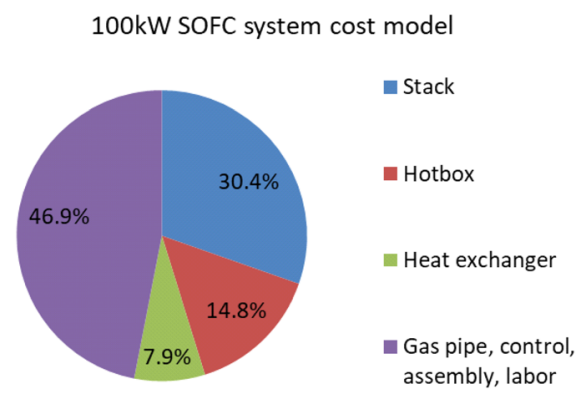

Fig. 14 Cost model of a $100 \mathrm{~kW}$-level SOFC system

generation system published by other developers of fuel cells. However, the stack cost may be slightly higher in our system because we purchased the stacks from the supplier and the labor cost for system assembly was counted in other cost rather than materials cost only. The heat exchanger was $7.9 \%$ and hotbox was $14.8 \%$, which are expected to be reduced significantly because it is a customized design and built in very small quantities. Upon mass production, it will become a standard product and the cost will be much lower. The major cost seems to be related to the BOP: gas-pipe materials; gas flow and pressure control meters; fuel and air preheaters or burner during system start-up; heat exchangers during system steady-state operation; blowers to transport exhaust fuel to the oxygen-combustor to burn residual fuel to $\mathrm{CO}_{2}$ and steam for $\mathrm{CO}_{2}$ enrichment; labor cost for system assembly. It is a demonstration unit, so the overall cost is higher. For a commercial product, the system cost (including materials and labor) can be reduced significantly.

Each subsystem consists of 5-6 SOFC modules which are connected electrically in parallel.

\section{Summary and conclusions}

(1) Economic analyses indicated that the advanced IGFC system (power degradation rate $=0.2 \%$ / $1000 \mathrm{~h}$ or lower) with $\mathrm{CO}_{2}$ capture is competitive compared with SCPC, and its COE can be up to $20 \%$ lower than that of SCPC. Captured $\mathrm{CO}_{2}$ can be stored or utilized through co-electrolysis with $\mathrm{H}_{2} \mathrm{O}$ to produce syngas again to achieve fuel-electricitywaste fuel cycle.

(2) Based on testing results, the SOFC stacks selected in our study showed good performance, consistency, and long-term stability. Average stack ASR was $0.31 \Omega-\mathrm{cm}^{2}$ in hydrogen. Under preferred testing conditions, the stack did not show noticeable degradation during $>500 \mathrm{~h}$ of long-term durability testing in hydrogen fuel and coal syngas, which indicated a potential long service life. When using syngas as fuel, the $\mathrm{H}_{2} / \mathrm{CO}$ ratio and steam/CO ratio must be controlled to avoid carbon deposition within the fuel pipe. $\mathrm{A}_{2} / \mathrm{CO}$ ratio of $1.68-2.8$ and steam/ $\mathrm{CO}$ ratio of 1 are acceptable. If the $\mathrm{H}_{2} / \mathrm{CO}$ ratio is low, the mixing of steam with syngas is important.

(3) A $20-\mathrm{kW}$ SOFC power-generation unit is being developed to verify technology feasibility. It consists of four stack towers. Each stack tower consists of $4 \times 1-1.5-\mathrm{kW}$ stacks, the power output of which is dependent on the fuel type and operating conditions. The maximum power output of the unit is expected to be $20 \mathrm{~kW}$ when using syngas as fuel. The CFD simulation of a $20-\mathrm{kW}$ module indicates that fuel flow was, in general, uniform among 16 stacks. Flow variation between stacks was less than $\pm 5 \%$. The $100 \mathrm{~kW}$-level subsystem can be built by duplicating 
$5-6 \times 20-\mathrm{kW}$ power-generation units, and the $\mathrm{MW}_{\text {th }}$ IGFC demonstration system (total input energy is MW and power output is $500 \mathrm{~kW}$ ) will consist of $5 \times 100 \mathrm{~kW}$-level subsystems.

(4) The operating conditions of the $20-\mathrm{kW}$ powergeneration unit, $100 \mathrm{~kW}$-level subsystem, and the $\mathrm{MW}_{\text {th }}$ IGFC demonstration system are a current density of $250 \mathrm{~mA} / \mathrm{cm}^{2}$ (14.9 $\mathrm{kW}$ power output for steady-state operation) and $336 \mathrm{~mA} / \mathrm{cm}^{2}$ (maximum 20-kW power output), respectively; fuel utilization of $80 \%$, DC power efficiency of $>50 \%$, stack inlet and outlet temperatures of $700{ }^{\circ} \mathrm{C}$ and $800{ }^{\circ} \mathrm{C}$, respectively. DC voltage output from a SOFC stack tower will be $>171 \mathrm{~V}$. A DC/DC booster may be required before $\mathrm{DC} / \mathrm{AC}$ conversion.

Acknowledgements The authors thank the Ministry of Science and Technology of the People's Republic of China for financial support under contract of 2017YEB061900. The authors also want to thank China Energy and Shenhua New Energy Co., Ltd. for providing cost share; Ningxia Coal Industry Co., Ltd. for their support in establishing the electrochemical testing center and providing a site for the field test of the $\mathrm{MW}_{\text {th }}$ IGFC system demonstration; and Professor Sun Yi at Harbin Institute of Technology for CFD simulation of stack module by his group. The discussion with Dr. Anthony $\mathrm{Ku}$ is helpful for putting together the section of economic analysis of the IGFC system.

Open Access This article is licensed under a Creative Commons Attribution 4.0 International License, which permits use, sharing, adaptation, distribution and reproduction in any medium or format, as long as you give appropriate credit to the original author(s) and the source, provide a link to the Creative Commons licence, and indicate if changes were made. The images or other third party material in this article are included in the article's Creative Commons licence, unless indicated otherwise in a credit line to the material. If material is not included in the article's Creative Commons licence and your intended use is not permitted by statutory regulation or exceeds the permitted use, you will need to obtain permission directly from the copyright holder. To view a copy of this licence, visit http://creativecommons. org/licenses/by/4.0/.

Funding Funding was provided by National Key R\&D Program of China (2017YFB0601900).

\section{References}

Braun RJ, Kameswaran S, Yamanis J, Sun E (2012) Highly efficient IGFC hybrid power systems employing bottoming organic rankine cycles with optional carbon capture. J Eng Gas Turb Power 134:021801

DOE/NETL (2014) Techno-economic analysis of integrated gasification fuel cell systems created by energy sector planning and analysis for SEAP \& OPPB/DOE/NETL-341/112613, November 24,2014

DOE/NETL (2013) Capital cost scaling methodology quality guidelines for energy system studies DOE/NETL-341/013113

DOE/NETL (2015) Cost and performance baseline for fossil energy plants volume 1b: bituminous coal (IGCC) to electricity. DOE/ NETL-2015/1727, July 31, 2015, Revision 2b-Year Dollar Update

Ghosh S, De S (2006) Energy analysis of a cogeneration plant using coal gasification and solid oxide fuel cell. Energy 31:345-363

Jiang X, Green C (2017) China's future emission reduction challenge and implications for global climate policy. J Clim Policy 18:889-901

Kobayashi Y, Tomida K, Nishiura M, Hiwatashi K, Kishizawa H, Takenobu K (2015) Development of next-generation large-scale SOFC toward realization of a hydrogen society. Mitzubishi Heavy Ind Tech Rev 52:111-116

Liese E (2010) Comparison of preanode and postanode carbon dioxide separation for IGFC systems. J Eng Gas Turb Power 132:6

National Energy Technology Laboratory (2009) Integrated gasification fuel cell performance and cost assessment. DOE/NETL$2009 / 1361$

National Energy Technology Laboratory (2013) Capital cost scaling methodology - quality guidelines for energy systems studies. DOE/NETL-341/013113

Nomura R, Ikl N, Kurata O, Kawabata M, Tsutsumi A, Koda E (2011) System analysis of IGFC with energy recuperation utilizing lowgrade coal. In: Proceedings of ASME Turbo Expo GT2011, pp 1-9

Singh S et al (2018) China baseline coal-fired power plant with postcombustion $\mathrm{CO}_{2}$ capture: 2. Techno-economics. Int J Greenhouse Gas Cont 78:429-436

Wang HL, Xue YP, Yu SE, Li PP, Li CF (2021) Study on the combustion of exhaust fuel from the SOFC system fed with coal syngas in pure oxygen for $\mathrm{CO}_{2}$ capture. Int $\mathrm{J}$ Coal Sci Technol 8

Xu M, Wang HL, Li PP, Zhang ZH, Li CF (2021) Performance test and verification of SOFC stack module with coal syngas feeding. Int J Coal Sci Technol 8 